\section{7}

\title{
Politics can be bad for your health: Trumpism and COVID-19 Outcomes
}

\author{
Brian M. Hicks ${ }^{1 *}$, D. Angus Clark ${ }^{1}$, Catherine Vitro ${ }^{1}$, Elizabeth Johnson ${ }^{1}$, Hannah A. Roberts ${ }^{2}$, \\ Carter Sherman $^{1}$, Mary M. Heitzeg ${ }^{1}$ \\ ${ }^{1}$ Department of Psychiatry, University of Michigan \\ ${ }^{2}$ Department of Psychology, Temple University
}

Funding: This work was supported by United States Public Health Service grants R01 AA024433 (Hicks), R01 AA02579 (Heitzeg), and T32 AA007477 (Blow) from the National Institute on Alcohol Abuse and Alcoholism. The funders had no role in study design, data collection and analysis, decision to publish, or preparation of the manuscript.

*Correspondence: Address correspondence to Brian M. Hicks, Ph.D., Department of Psychiatry, University of Michigan, brianhic@ umich.edu (BH) 


\section{Abstract}

The political rise of Donald Trump and the ideology of Trumpism has had a major impact on American politics, culture, and its response to the COVID-19 pandemic. We began the process of validating a psychometric model of Trumpism using three waves $(\sim 1000$ participants per wave) of data from national online surveys of adults conducted in the United States from June 2020 to February 2021 as part of the COVID-19 Adjustment and Behaviors Survey. We found that the covariance among measures of Trump approval and attitudes about race, immigration, policing, guns, and media bias were best accounted for by a single Trumpism factor, and that this factor was strongly related to attitudes about a rigged 2020 Presidential election, the Insurrection of January 6, 2021, and Trump idolatry. Trumpism was also associated with Republican party affiliation and White race, but had only small associations with age, sex, income, and education. Trumpism was associated with increased odds of a positive COVID-19 diagnosis, skepticism about the seriousness of COVID-19, lack of support for government restrictions to reduce the spread of COVID-19, less adherence to social distancing and mask

44 wearing guidelines, anti-vax attitudes, and hesitancy to receive a COVID-19 vaccine. Results 45 indicate these measures provide a valid assessment of Trumpism which is likely to continue to play a major role in American political and cultural life for the foreseeable future. 


\section{Introduction}

Donald Trump's ascension to the Presidency of the United States has been one of the most significant events in 21st century American politics. His dominance of the Republican

56 party, one of the two major political parties in the United States, was built upon an explicit

57 embrace of White identity and grievance politics, anti-rationalism, the denial of empirical reality

58 in favor of constructed fictions, and an authoritarian cult of personality [1-5]. Although he failed

59 to win re-election, Trump and his ideology retains a dominant position in the Republican party.

60 Indeed, his unsuccessful attempts to undermine and overturn the results of the 2020 Presidential

61 election has provided a blueprint for Republicans to contest the results of future elections.

62 Specifically, Republican majorities in state legislatures in collaboration with Republican

63 governors have worked to change laws to suppress the votes of citizens less likely to vote for

64 Republican candidates and, more ominously, allow political partisans to overturn elections

65 through "legal" means (e.g., failing to certify election results) [6-9]. Consequently, Donald

66 Trump and the broader construct of Trumpism as a political ideology will continue to have a

67 large influence on American politics and American life for the foreseeable future. It is thus

68 critical to study Trumpism as a coherent worldview to better understand its structure, facets, and

69 associations with consequential outcomes (e.g., behavior in response to a global pandemic).

\section{$70 \quad 2016$ presidential election}

We propose that Trumpism includes several core facets that are a function of Trump's

72 political rise, his actions in office, and long-term trends in conservative and Republican politics.

73 Prior to his election, Trump rose to prominence in the political media as a vocal skeptic of the 
American citizenship of former President Barack Obama, a debunked conspiracy theory referred to as "birtherism" [10]. Birtherism provided an implicit way to tie Obama's mixed race and ancestry (White American mother and Black Kenyan father) to a lack of political legitimacy and otherness (i.e., non-American, non-native born, non-White) [11-12]. This tactic follows from the American conservative movement's long-standing use of "dog whistles" in political discourse, that is, indirect references to negative stereotypes associated with racial minorities [13]. This strategy is a manifestation of the perspective that non-White people (especially Black and Indigenous Americans) and immigrants do not have a legitimate claim to political participation and political power. Consistent with this history and Trump's embrace of birtherism, the leading issue of his campaign in the 2016 election was border security and immigration where he claimed that poor, violent, non-White people from Latin American countries were overrunning the U.S. southern border and contributing to crime and economic loss (e.g., "they're sending their rapists, their murders,...”, taking jobs from Americans; [14-15]). Trump also disparaged Muslims living in and traveling to the U.S., drawing implicit and explicit connections to terrorists that perpetrated the $9 / 11$ and other terror attacks $[16,14]$.

Trump's emphasis on border security drew him into a political alliance with unions representing U.S. Border Patrol and Immigration and Customs Enforcement (ICE) agents, as well as some higher-ranking officials in these agencies [17-19]. Trump's coalition with security forces quickly expanded to include majorities of the rank-file of local and state police departments, and federal agencies such as the Federal Bureau of Investigation (FBI) [20-21]. Political alignment among security forces and conservative political parties has a long-history, for example, Richard Nixon's call for "law and order" in the 1968 presidential election [22-23]. The intensity of the support for Trump, however, was notably stronger than that observed for 
97 prior presidential candidates. For example, groups of police officers were photographed wearing

98 Trump's signature Make America Great Again (MAGA) hats while in uniform [24-25], a

99 controversial action which raises questions as to whether police would act in an unbiased manner

100 when interacting with citizens that do not share their political attitudes. Some critics also noted

101 that the alignment with police forces dovetailed with what they claimed were Trump's racist

102 attitudes towards non-White people in general [26], as there is a long and contentious

103 relationship between police and non-White citizens. Specifically, there is evidence that police

104 often mistreat non-White people or enforce the law in racially biased ways [27-29].

105 Trump also forged alliances with two single issue voter groups: gun rights activists and

106 socially conservative anti-abortion Christians. Although gun regulation had already been

107 politically polarized by 2016 with gun rights advocates firmly in the Republican coalition,

108 Trump endorsed the most extreme gun rights positions and rhetoric of any 2016 presidential

109 candidate [30]. Trump also gained unshakeable popularity among socially conservative

110 Christians after reversing his position on abortion and avowing a firm anti-abortion position [31-

$11132]$, despite his well-publicized personal and public life that included numerous examples of

112 behaviors and attitudes that seemingly contradict the ethical and moral perspectives espoused by

113 socially conservative Christians (e.g., adultery, multiple marriages, lying, failing to honor

114 business agreements).

115 Finally, Trump engaged in a contentious, though some have argued symbiotic,

116 relationship with certain media companies, the so-called "mainstream" media (e.g., CNN, legacy

117 television network news, The New York Times, The Washington Post) [33-34]. Trump

118 complained that coverage from these news outlets was not only negative but also biased and

119 inaccurate, using the term "fake news" to describe their coverage [35]. These claims flowed from 
120 the long-standing complaints of political conservatives that the mainstream media is liberally

121 biased and unfair to Republican politicians [36]. Trump, however, intensified these complaints,

122 going so far as to refer to journalists as "enemies of the people" [37-38].

123 To summarize, some of the key tenets that characterize Trumpism include grievance and

124 hostility to non-White minorities, immigrants, and Muslims with an emphasis on closing the

125 border and "building the wall"; aligning with police and other security forces with an emphasis

126 on "law and order" and the punitive use of law enforcement powers, particularly against political

127 adversaries (e.g., the "Lock her up" phrase in reference to Hillary Clinton the Democratic

128 candidate of the 2016 Presidential election); alignment with single-issue voters within the

129 conservative coalition especially gun rights and anti-abortion activists; and open conflict with the

130 media to undermine negative coverage, aka, "fake news". Following his victory in the 2016

131 presidential election, many of the facets of Trumpism observed in the campaign were evident

132 and seemed to intensify during his time in office. Trump's grip on the Republican party grew

133 stronger as even moderate disagreements led to officials retiring or being purged from the party

134 [39-41]. Although there remained remnants of a more traditional conservative movement

135 political orientation (e.g., lower taxes, fewer government services, and less government

136 regulation), Republican politics increasingly took on a Trumpist orientation of White grievance

137 politics, authoritarianism, and a cult of personality around Donald Trump.

\section{COVID-19 pandemic}

Though Trump never enjoyed majority support, he maintained a seemingly unbreakable

140 coalition of supporters despite numerous scandals (including an impeachment trial, January 16-

141 February 5, 2020) and was a formidable candidate for re-election in 2020. By March 2020,

142 however, the COVID-19 pandemic was such a disruptive event that it quickly became the 
143 nation's dominant political issue. Rather than treating COVID-19 as a non-partisan public health

144 crisis, Trump approached the pandemic as a political issue to be managed by polarizing various

145 aspects of the government response along partisan lines [42-44]. Trump also downplayed the

146 severity of the disease, advocated a relatively quick lifting of the government restrictions in-

147 place to mitigate the spread of the virus (e.g., stay at home directives, ban on public gatherings),

148 and sent mixed messages about wearing face coverings [45]. Trump also publicly feuded with

149 state officials who requested greater federal support and maintained stricter restrictions

150 undermining efforts for a coordinated national strategy to manage the pandemic [46-48].

151 These attitudes evolved into what we call COVID-19 skepticism, or the downplaying of

152 the health risks associated with COVID-19, and opposition to mitigation strategies [49-50]. In

153 spite of this skepticism, the Trump administration's key strategy to resolving the COVID-19

154 pandemic was to focus on vaccine development, despite having strong support among

155 conservative anti-vaxxer groups [45]. However, Trump's downplaying of the severity of

156 COVID-19, the emergence of COVID-19 skepticism, and Trump and other conservatives'

157 critiques of scientific and government institutions has led Trump supporters to endorse high

158 levels of COVID-19 vaccine hesitancy [50].

$159 \quad 2020$ presidential election

The 2020 presidential election occurred amidst the COVID-19 pandemic. Trump's

161 strategy for dealing with the pandemic seemed to be guided by the desire to return to pre-

162 pandemic economic activity as soon as possible. Layered on top of the pandemic and election,

163 however, was a summer of Black Lives Matter (BLM) protests (the largest mass protests in U.S.

164 history) [51] against police violence and mistreatment following the murder of George Floyd on

165 May 25, 2020 by a police officer in Minneapolis, MN [52]. Initially, this wave of protests was 
166

167

168

169

170

171

172

173

174

175

176

177

179

180

181

182

183

184

185

186

187

188

associated with a significant shift in support among White Americans toward the BLM position [53]. As the protests continued throughout the summer, however, street clashes with police, rioting, and controversy over the concept of "defunding the police" further polarized the issue of the role of police and debate over the centrality and divisive nature of race in American society [54-55]. Trump remained steadfast in his alliance with police, hostile to the concept of defunding and dismissive of the importance of race and racial inequities in America's history and society more generally [56-57]. Consequently, holding pro-police attitudes-as well as anti-BLM and anti-racially conscious attitudes-became even more strongly solidified as a core element of Trumpism, which was most clearly evident at Trump's political rallies in the fall of 2020, where "Blue Lives Matter" flags-a counter movement to Black Live Matter that advocates that violence against police officers should be prosecuted as hate crimes-gradually increased in size and eventually displaced the U.S. national flag [58].

While the BLM protests peaked in the early summer, COVID-19 mitigation strategies (e.g., restricting social activities, social distancing, mask wearing) seemed to have been effective in assuaging an overflow of emergency medical care and to have contained the spread of the virus [59-60]. As restrictions were relaxed, however, a second wave soon followed in the mid-tolate summer of 2020 in various parts of the country [61-62], and then a much larger third wave that engulfed most of the country in the fall and early winter [63-64]. During this time, the U.S. led the world in COVID-19 cases and deaths accounting for a disproportionate number of both [65] (i.e., U.S. accounted for over $20 \%$ of global COVID-19 cases and deaths, but only $5 \%$ of the world population [66]. By the fall of 2020 any attempt at a coordinated response to the pandemic had seemingly collapsed with states largely left alone to deal with their local conditions [67-68], while COVID-19 related deaths exceeded 200,000 Americans on September 22, 2000 [69]. 
Despite the health and economic crisis of COVID-19, racial turmoil, and his consistently

190

191

192 negative approval ratings, Trump remained a competitive candidate in 2020 presidential election due to his reliable base of support and the indirect way that U.S. presidents are elected (i.e., weighted state-level electoral results rather than through a national popular vote) [70]. If anything, the political polarization over COVID-19, race, and policing seemed to intensify support for Trump among his base voters. Indeed, throughout the course of the election, Trump's campaign and persona drifted even further into a cult of personality. For example, the Republican party did not publish a new platform for the 2020 election and merely stated support for President Trump and his policies, whatever they may be [71]. As in 2016, Trump continued to make statements that only he could solve the nation's problems [72-73], a sentiment that was endorsed by more and more of his followers.

Ultimately, however, the election returns indicated Trump lost the 2020 presidential election to Joe Biden [74]. Losing the vote count, however, did not deter Trump from attempting to retain the presidency. Trump and his allies made numerous claims of voter fraud and election irregularities and filed dozens of lawsuits, a strategy he foreshadowed during the campaign by consistently stating his loss would only be possible due to cheating or voter fraud [75-76]. Federal and state officials found no evidence of widespread fraud or irregularities and none of the lawsuits were successful [77]. Still, Trump and his allies persisted in making false claims, spreading conspiracy theories, and attempting to influence the vote count and certification process in an explicit attempt to overturn results of the election [78]. Although these efforts were not successful, they had a dramatic impact on public opinion [79-80]. Among Trump supporters, a significant majority came to believe the "Big Lie", that is, that the election was stolen from Trump [81]. 
Trump and his allies continued to push the Big Lie and attempt to disrupt the transfer of

213 power. The last legal procedure to conclude the 2020 election was the ceremonial act of

214 Congress counting and then certifying the electoral college votes on January 6, 2021 [82]. On

215 that day, Trump spoke at a rally called "Stop the Steal" and encouraged his followers to go to

216 Congress to "make their voices heard" [83]. The crowd then stormed the U.S. Capitol to stop the

217 certification process, in what became known as the January $6^{\text {th }}$ Insurrection. Order was

218 eventually restored, and the electoral votes certified [84]. Trump then acknowledged that a new

219 administration would take power though he never mentioned Biden's name [85] and has never

220 conceded that he lost the election. Trump was impeached for a second time for his role in

221 inciting his followers to insurrection [86] though the Senate failed to convict him of the charge

222 (conviction requires a two-thirds majority [87]).

\section{Defining the psychometric structure of Trumpism}

Although Donald Trump is no longer president, he looms large in Republican politics.

225 The debunked conspiracy theory of the Big Lie has become a normative attitude within the

226 Republican party, and Trump remains the leading candidate for the 2024 Presidential election

227 [88-90]. Further, his approach to White identity and grievance politics has become a dominant

228 electoral strategy among Republicans. Finally, and most ominously, Republicans have embraced

229 a strategy of changing rules for voting and election processing that curtails the representation of

230 demographic groups that are less likely to vote for Republican candidates and provides more

231 opportunities to "legally" challenge or overturn an election [91]. Consequently, Trumpism as a

232 broader political perspective requires an intensive study to understand the directions of American

233 politics for the foreseeable future. 
We report our efforts to define the psychometric structure of Trumpism using a series of online surveys of adults living in the United States that were completed from June 2020 through February 2021. The measures we included changed over time as social and political events

237 unfolded and relevant constructs emerged. We began with an emphasis on approval ratings of

238 President Trump as well as attitudes about immigration, race, policing, and guns. We then 239 expanded this assessment to include attitudes about the news media ("fake news"), Trump 240 idolatry, the Big Lie, and the January $6^{\text {th }}$ insurrection. Our first goal was to examine the structure

241 of these measures, for example, if a single dominant factor could explain their covariance 242 consistent with a unified political ideology and coalition, or if this was better described by 243 multiple correlated factors, representing a more dispersed political coalition. We then examined 244 demographic correlates of the resulting factors. Specifically, we predicted Trumpism would be 245 associated with White race, older age, and lower education based on prior media reports and 246 polling results [92]. Finally, to demonstrate the impact of Trumpism on important outcomes, we 247 also examined the associations between Trumpism and COVID-19 related variables including 248 risk of a COVID-19 diagnosis, support for government restrictions to mitigate risk, safety 249 behaviors including mask wearing and social distancing, COVID-19 skepticism, and vaccine 250 hesitancy.

\section{Methods}

\section{Sample ascertainment}

Data were collected at three different time points as part of the COVID-19 Adjustment and Behavior Survey: June 9 through June 22, 2020; September 24 through October 25, 2020; and January 14 through February 25, 2021. Recruitment entailed an actively managed, double- 
256

257

258

259

260

261

262

263

264

265

266

267

268

269

270

271

272

273

274

275

276

277

278

opt-in research panel with Qualtrics XM survey software. Recruitment was designed to ascertain a sample similar to the United States general population using quotas for the demographic variables of age, sex, and race that were monitored while the survey was in field. Respondents were recruited using a dashboard-style web page on the Qualtrics website and cellphone app where participants see a list of surveys that they have the option to participate in. Recruitment was also conducted through emails sent to established panel members within the Qualtrics database. In all recruitment methods, potential participants received information on the estimated length of the survey and compensation for completing it. Specific details about the survey content were not available until the participants opted-in to avoid self-selection bias. Upon opting into the study, participants read and provided an electronic signature on a consent form containing an overview of the survey contents. Participation was voluntary and anonymous as no individually identifying information was collected. Contact information for the research team was provided in case participants had questions about the survey. The University of Michigan Medical School Institutional Review Board (IRB) reviewed all study protocols. After participating in a survey wave, attempts were made to recontact respondents to participate in all subsequent wave(s). Following wave 1, new respondents were allowed to join the study once participation by prior respondents plateaued to maintain a consistent sample size $(\sim 1000$ participants) while still maintaining quotas for the specified demographic variables across waves.

After the surveys were closed, the data was manually checked and a small number of respondents (six in wave 1, 20 in wave 2, 13 in wave 3) were excluded due to inconsistent and illogical responses. Single measures were also excluded on a case-by-case basis if all other responses from that participant were within a plausible range of values. The final sample sizes 
were 1008,1004 , and 1005 participants for waves 1,2 , and 3, respectively, with 1848 unique participants. For the number of assessments completed, 1012 participants completed one wave, 503 completed two waves, and 333 completed three waves. The median response time for completing the surveys ranged from 23.2 to 28.1 minutes.

Table 1 reports the demographic characteristics of the sample organized by wave. The demographic characteristics of each wave were similar to those reported by the US Census Bureau for the United States population for 2019 for age, sex, and race. However, the years of education were consistently higher in the surveys relative to the U.S. population. Mean educational level was higher than the US general population due to lower rates of people with a high school diploma or less (17.0\% sample vs. 39.0\% U.S. general population) and higher rates of people with bachelor (34.2\% sample vs. $19.0 \%)$ and graduate degrees (22.5\% sample vs. 11.0\%). Mean household incomes were similar to the U.S. general population with lower incomes $(<\$ 50,000)$ slightly underrepresented $(34.3 \%$ sample vs $37.8 \%)$, middle incomes $(\$ 50,000$ to $\$ 100,000)$ overrepresented (33.8\% sample vs $28.6 \%)$, and higher incomes (> $\$ 100,000)$ comparably represented (31.9\% sample vs $33.6 \%)$. In terms of political party affiliation, persons affiliated with the Democratic party (39.4\% sample vs 33.0\%) were overrepresented while persons affiliated with the Republican party (27.3\% sample vs $29.0 \%$ ) and persons identified as independent or not registered with a political party (29.2\% sample vs $34.0 \%)$ were underrepresented relative to the general electorate [92]. Four percent of our sample identified with another political party (Libertarian, Green, Constitution, or other). 
302 Table 1. Demographics and Political Affiliation.

\begin{tabular}{|c|c|c|c|c|}
\hline & $\begin{array}{c}\text { Total }^{\mathrm{a}} \\
(N=1848)\end{array}$ & $\begin{array}{c}\text { Wave } 1 \\
(n=1008)\end{array}$ & $\begin{array}{l}\text { Wave } 2 \\
(n=1004)\end{array}$ & $\begin{array}{l}\text { Wave } 3 \\
(n=1005)\end{array}$ \\
\hline & $\%(n)$ & $\%(n)$ & $\%(n)$ & $\%(n)$ \\
\hline \multicolumn{5}{|l|}{ Sex } \\
\hline Male & $46.9(867)$ & $47.4(478)$ & $48.9(491)$ & $49.2(494)$ \\
\hline Female & $53.1(981)$ & $52.6(530)$ & $51.1(513)$ & $50.8(511)$ \\
\hline \multicolumn{5}{|l|}{ Age $^{\mathrm{b}}$} \\
\hline $18-29$ & $23.4(432)$ & $18.1(182)$ & $17.8(179)$ & $18.0(181)$ \\
\hline $30-39$ & $21.7(401)$ & $20.6(208)$ & $19.8(199)$ & 19.8 (199) \\
\hline $40-49$ & $17.2(318)$ & $18.3(184)$ & $17.2(173)$ & $17.5(176)$ \\
\hline $50-59$ & $14.6(270)$ & $14.9(150)$ & $16.3(164)$ & $16.1(162)$ \\
\hline $60-69$ & $14.6(270)$ & $17.7(178)$ & $17.6(177)$ & $17.4(175)$ \\
\hline $70+$ & $8.4(156)$ & $10.5(106)$ & $11.2(112)$ & $11.1(112)$ \\
\hline \multicolumn{5}{|l|}{ Race and Ethnicity ${ }^{\mathrm{c}}$} \\
\hline White & $79.1(1462)$ & $77.2(788)$ & $76.8(771)$ & $77.3(777)$ \\
\hline Black & $13.9(257)$ & $14.0(141)$ & $14.6(147)$ & $13.7(138)$ \\
\hline Native American & $1.0(19)$ & $0.9(9)$ & $0.7(7)$ & $1.2(12)$ \\
\hline Asian & $5.3(98)$ & $6.0(60)$ & $6.2(62)$ & $6.2(62)$ \\
\hline Native Hawaiian & $0.1(2)$ & $0.0(0)$ & $0.1(1)$ & $0.1(1)$ \\
\hline Don't know & $0.1(2)$ & $0.1(1)$ & $0.1(1)$ & $0.1(1)$ \\
\hline Some other race & $1.5(28)$ & $1.6(16)$ & $1.8(18)$ & $1.2(12)$ \\
\hline Hispanic - any race & $17.9(331)$ & $17.7(178)$ & $17.7(178)$ & $17.3(174)$ \\
\hline \multicolumn{5}{|l|}{ Education } \\
\hline Less than high school & $2.7(49)$ & $1.6(16)$ & $3.1(31)$ & $1.6(16)$ \\
\hline High school diploma & $14.3(265)$ & $9.6(97)$ & $14.2(143)$ & $14.2(143)$ \\
\hline Some college & $26.2(485)$ & $24.1(243)$ & $25.7(258)$ & $26.9(270)$ \\
\hline Bachelor's degree & $34.2(633)$ & $38.8(391)$ & $34.7(348)$ & $32.9(331)$ \\
\hline Master degree & $18.1(334)$ & $21.5(217)$ & $17.7(178)$ & $19.6(197)$ \\
\hline Doctorate & $4.4(82)$ & $4.4(44)$ & $4.6(46)$ & $4.8(48)$ \\
\hline \multicolumn{5}{|l|}{ Annual Household Income } \\
\hline Less than $\$ 50,000$ & $34.3(634)$ & $29.1(293)$ & $34.2(343)$ & $32.2(323)$ \\
\hline$\$ 50,000-\$ 99,999$ & $33.8(625)$ & $35.6(359)$ & $33.2(334)$ & $35.4(356)$ \\
\hline$\$ 100,000+$ & $31.9(589)$ & $35.2(356)$ & $32.6(327)$ & $32.5(326)$ \\
\hline \multicolumn{5}{|l|}{ Political Affiliation } \\
\hline Democratic & $39.4(729)$ & $41.6(419)$ & $39(392)$ & $41.7(419)$ \\
\hline Republican & $27.3(504)$ & $25.9(261)$ & $26.5(266)$ & $25.6(257)$ \\
\hline Independent/Not Registered & $29.2(539)$ & $29.6(298)$ & $31.5(316)$ & $28.4(286)$ \\
\hline Third Party & $4.1(76)$ & $3(30)$ & $3(30)$ & $4.3(43)$ \\
\hline
\end{tabular}

${ }^{a}$ Total sample refers to the number of unique individuals across waves

${ }^{\mathrm{b}}$ One participant is missing age data

${ }^{c}$ For race, participants were allowed to select all that apply. Two participants are missing race data. 
304 Measures

\section{Demographics}

306 Demographic characteristics used in the prediction models included age, sex assigned at

307 birth (male, female), race (White, non-White), annual household income, and educational 308 attainment.

\section{Trumpism facets}

310 Table 2 provides a list of the scales used to measure Trumpism facets organized by the 311 assessment wave (Summer 2020, Autumn 2020, Winter 2021). The table provides a description

312 of the content, an example item, the number of items and the marginal reliability for each scale

313 derived from graded response models. The online supplemental material also provides the

314 content of each item (Tables S1 to S13; OSF. Unless noted otherwise, the items used a 6-point

315 response option of strongly agree, agree, slightly agree, slightly disagree, disagree, strongly

316 disagree). 
Table 2. Summary of Scales at Each Wave of Data Collection.

\begin{tabular}{|c|c|c|c|c|}
\hline & Content & Sample Item & \# Items & Marginal Reliability \\
\hline \multicolumn{5}{|l|}{ Summer 2020} \\
\hline Police Attitudes & $\begin{array}{l}\text { Policing in general, racial bias in } \\
\text { policing, and police response to } \\
\text { protest }\end{array}$ & $\begin{array}{l}\text { The police treat black and } \\
\text { white people equally. }\end{array}$ & 10 & .93 \\
\hline $\begin{array}{l}\text { Race \& Immigration } \\
\text { Attitudes }\end{array}$ & Immigration and systemic racism & $\begin{array}{l}\text { If America is too open to } \\
\text { people from all over the } \\
\text { world, we risk losing our } \\
\text { identity as a nation. }\end{array}$ & 6 & .89 \\
\hline \multicolumn{5}{|l|}{ Autumn 2020} \\
\hline Police Attitudes & $\begin{array}{l}\text { Police, police bias, and police } \\
\text { response to protest }\end{array}$ & & 11 & .93 \\
\hline $\begin{array}{l}\text { Race \& Immigration } \\
\text { Attitudes }\end{array}$ & Immigration and systemic racism & & 6 & .89 \\
\hline Media Bias & $\begin{array}{l}\text { Media bias against conservative } \\
\text { viewpoints }\end{array}$ & $\begin{array}{l}\text { The mainstream media makes } \\
\text { things up. }\end{array}$ & 6 & .92 \\
\hline Pro-Gun Attitudes & $\begin{array}{l}\text { Utility and legality of gun } \\
\text { ownership }\end{array}$ & $\begin{array}{l}\text { The best defense against a } \\
\text { tyrannical government is a } \\
\text { well-armed citizenry. }\end{array}$ & 4 & .84 \\
\hline \multicolumn{5}{|l|}{ Winter 2021} \\
\hline Police Attitudes & $\begin{array}{l}\text { Police, police bias, and police } \\
\text { response to protest }\end{array}$ & & 8 & .91 \\
\hline $\begin{array}{l}\text { Race \& Immigration } \\
\text { Attitudes }\end{array}$ & Immigration and systemic racism & & 6 & .89 \\
\hline Media Bias & $\begin{array}{l}\text { Media bias against conservative } \\
\text { viewpoints }\end{array}$ & & 6 & .91 \\
\hline Pro-Gun Attitudes & $\begin{array}{l}\text { Utility and legality of gun } \\
\text { ownership }\end{array}$ & & 4 & .85 \\
\hline Rigged Election & $\begin{array}{l}\text { The } 2020 \text { election was unfair } \\
\text { against Donald Trump }\end{array}$ & $\begin{array}{l}\text { Democrats cheated their way } \\
\text { into winning the } 2020 \\
\text { election. }\end{array}$ & 7 & .86 \\
\hline Pro-Insurrection & $\begin{array}{l}\text { Support for the pro-Trump } \\
\text { protestors at the January } 6^{\text {th }} \text { Capitol } \\
\text { Insurrection }\end{array}$ & $\begin{array}{l}\text { The Pro-Trump protesters are } \\
\text { patriots who are trying to } \\
\text { protect our democracy. }\end{array}$ & 7 & .84 \\
\hline Trump Idolatry & $\begin{array}{l}\text { Donald Trump is a uniquely } \\
\text { capable, trustworthy president. }\end{array}$ & $\begin{array}{l}\text { Only President Trump is } \\
\text { capable of solving the } \\
\text { nation's problems. }\end{array}$ & 4 & .77 \\
\hline
\end{tabular}

Content = brief summary of scale content; \# Items = the number of items in a scale at a particular wave of assessment. The full list of items for each scale at each wave of assessment can be found in the online supplement (OSF). The marginal reliability estimates 
were derived from scale-specific graded item response models; the full results from these models can also be found in the online supplement (OSF).

317

318 Trump approval and political affiliation

Participants reported their approval for President Trump in general and which political party they were most affiliated with.

\section{Attitudes about race and immigration in the United States}

We used six items from a 2019 Pew Research Center poll to assess attitudes about race

gone far enough, (2) Been about right, (3) Gone too far.) and immigration (e.g., If America is too

open to people from all over the world, we risk losing our identity as a nation.) (In a Politically

Polarized Era, Sharp Divides in Both Partisan Coalitions, 2019) $(\alpha=.89)$.

\section{Attitudes about police and racial bias in policing}

We used eight to 11 items that asked participants about their perceptions of police misconduct (e.g., Police misconduct is mostly due to institutional forces such as racism and the "code of silence" among police officers.), racial bias in policing (e.g., The police treat Black and tactics such as the use of tear gas, mace, and rubber bullets against citizens in recent protests against police brutality) $(\alpha=.93)$.

\section{Pro-gun attitudes}

At each wave, we used the following item to assess attitudes about state regulations on 
339 about gun ownership (e.g., The best defense against a tyrannical government is a well-armed

340 citizenry) to create a scale of assessing attitudes about guns and gun ownership $(\alpha=.84)$.

341 Media bias

We used six items that asked respondents to report their agreement with statements about partisan biases in news sources either to a specific news source (e.g., CNN is fake news.) or news

344 bias in general (e.g., The mainstream media is biased against conservative viewpoints.) $(\alpha=$ $345.92)$.

346 Trump idolatry

We used four items to assess reverence for former President Donald Trump (e.g., Only President Trump is capable of solving the nation's problems. $)(\alpha=.77)$.

We used seven items to assess perceptions of the 2020 presidential election results (e.g., Democrats cheated their way into winning the 2020 election.) $(\alpha=.86)$.

We used five items that asked respondents to report their agreement with statements

354 about the attempted insurrection of the Capitol on January 6, 2021 (e.g., The Pro-Trump protesters are patriots who are trying to protect our democracy) $(\alpha=.84)$. were asked if they had been tested for COVID-19. If they responded, "Yes, and the results were positive," they were coded as positive for our narrow definition of a COVID-19 diagnosis. For 
361 the broad definition of a COVID-19 diagnosis, participants were coded positive if they meant the

362 narrow definition and if they also responded, "No, but I was given a medical diagnosis of

363 COVID-19" or "No, but I assume I currently have COVID-19 or had COVID-19 in the past".

364 COVID-19 related safety behaviors and attitudes about government mandates

365

366

367

368

369

370

371

372

373

374

375

376

377

378

379

380

381

\section{and restrictions}

For safety behaviors, participants were asked how often they followed the "social distancing", or "shelter-in-place" restrictions put in place in your community in the past three months, and how often they wear a mask in public, both indoors and outdoors (never, seldom, sometimes, often, always). Participants were also asked three questions to assess attitudes about government responses to COVID-19 including the necessity of COVID-19 related restrictions (very necessary, necessary, somewhat necessary, neither necessary or unnecessary, somewhat unnecessary, unnecessary, very unnecessary), approval of their state government's social distancing restrictions (strongly approve, approve, somewhat approve, somewhat disapprove, disapprove, strongly disapprove), and attitudes about the pace at which their community was lifting social distancing restrictions (much too soon, somewhat too soon, about right, somewhat too late, much too late $)(\alpha=.83)$.

\section{COVID-19 skepticism}

We used four items that asked participants to rate their level of agreement with statements about the severity COVID-19 and the public life consequences of the pandemic (e.g., COVID-19 is no worse than the flu) $(\alpha=.91)$.

\section{Anti-vax scale}


We used four items assessing general support for vaccinations to assess anti-vaccination

383 (i.e., anti-vax) attitudes (e.g., Vaccines are more dangerous than the diseases they are trying to

384 prevent. $)(\alpha=.91 ;[93]$.

385 COVID-19 vaccine hesitancy

We assessed openness to receiving a vaccination for the COVID-19 virus by asking,

"How likely are you to get a COVID-19 vaccine that has gone through the normal protocol for

388 development (e.g., clinical trials, tests for safety and efficacy)?” (very unlikely, unlikely, likely,

389 very likely) [93].

390 Data analytic strategy

Figure 1 lists the four steps of the data analysis plan. First, to establish the internal

392 validity of each scale, we evaluated their psychometric properties separately at each wave of

393 assessment. To do so, item factor analyses (IFA; [94] were used to characterize the dimensional

394 structure of the scales. Next, graded item responses models [95] were fit to each scale to examine

395 specific item properties and test reliability. These models assume unidimensionality-or at least

396 essential unidimensionality-which was one reason for the initial IFAs.

Figure 1. Data Analytic Strategy.

All steps were conducted for each individual wave of data collection in-turn.

Step two entailed testing whether the items and scales exhibited a coherent structure

398 consistent with a broader Trumpism construct. For example, was there evidence that a single

399 factor could account for a substantial portion of the covariance across scales or for the

400 covariance among the items across scales? First, we applied IFAs to the entire item-pool for a

401 given wave to examine whether a single factor could account for the item-level covariance. Next, 
we fit higher-order Trumpism factor models at each wave of assessment, which are depicted in Figure 2. In these models, lower-order factors were first specified in accordance with the original formulations of the scales as analyzed in step one. All items associated with a specific scale were specified to load on that scale's lower order-factor, and no other. Lower-order factor intercepts and residual variances were fixed to 0 and 1 , respectively. The lower-order factors were then all specified to load on the higher-order Trumpism factor. The mean and variance of the higherorder Trumpism factor was fixed to 0 and 1, respectively. Notably, at each wave of assessment there was a single item measuring general approval of Donald Trump, and in the Summer 2020 assessment a single item measuring attitudes about gun laws. These single-item measures were also specified to load on the higher-order Trump factor. Lower- and higher-order factor scores were then estimated using Expected A Posteriori (EAP) scoring methods.

\begin{abstract}
Figure 2. Conceptual diagram of the Trumpism higher order factor models. This is specifically a conceptual diagram for the Winter 2021 higher order factor model; fewer items and factors were included in the models for Summer and Autumn 2020. Individual items $\left(i_{1} \ldots i_{42}\right)$ were specified to load on a single lower order factor corresponding to their scale of origin; the lower order factors--and the single item assessing Trump Approval--were then specified to load on the higher order Trumpism factor. All factor means and variances/residual variances were fixed to 0 and 1 , respectively. Mean structure and variances/residual variances omitted from figure for clarity of presentation.
\end{abstract}

We used a higher-order model here as the structure was more consistent with our conceptual approach to the development of the Trumpism scales in this study, and to generate both Trumpism and non-residualized lower order factor scores for future use. We do not mean to imply, however, that the psychological structure of political ideology generally follows a higherorder factor model form. Indeed, several other types of models could also effectively be used to represent the covariation across scales/items [96]. For example, bifactor models when fit to this 
data produce Trumpism factor scores that correlate extremely highly $(r s \geq .95)$ with the higherorder derived scores used here.

While steps one and two examined internal validity, steps three and four examined external validity by testing the associations between the higher-order Trumpism factor and criterion variables. Step three entailed fitting a series of multiple regression models to explore how key demographic characteristics were associated with the Trumpism scores at each wave. Sex (female versus male) and race (non-White versus White) were included in each model. We also examined the impact of age, income, and education in turn with sex and race, including all potential two-way and three-way interaction terms. Age, income, and education were grand mean centered prior to the computation of the interaction terms. We only included one nonbinary predictor in each model to limit the number of interaction terms and to keep the models feasible given the sample size. Like the other analyses reported here, these models were exploratory, and can provide direction for future investigations into the trends reported here. For step four, we examined correlations between the higher-order Trumpism factor and several COVID-19 related behaviors and outcomes at each wave. Like the demographic models, these are meant to provide a broad, concise overview of how the Trumpism factors are associated with a variety of variables that may be of interest in future, more targeted investigations.

The item responses models were run in flexMIRT version 3.52 [97] using full information maximum likelihood estimation. The IFAs and higher-order factor models were run in Mplus version 8.5 using weighted least squares with mean and variance adjustment (WLSMV) estimation [98]. The multiple regression models and correlation analyses were also run in Mplus using full information maximum likelihood estimation. Confidence intervals for the multiple 
441 regression models were derived via percentile bootstrapping with 10,000 random draws, which

442 performs well across a variety of data contexts [99].

\section{Results}

\section{Individual scale functioning}

Scree plots for the IFAs revealed a mean first to second eigenvalue of 4.54 to 0.69 (or

6.58 to 1; see Table S14 in online supplement for the first five eigenvalues associated with every

IFA), indicating each scale had a dominant first factor. Further, extracting multiple factors effectively unidimensional.

The graded response models indicated each individual scale was coherent and reliable.

The results from each graded response model-including item discrimination values, standardized factor loadings, information at selected values of the latent factor, and marginal reliability-can be found in the online supplement (Tables S15 through S27; OSF). In general, the items had high

454 discrimination values, with most item discrimination values above $a=.80$ (this corresponds to a 455 standardized factor loading of around $\lambda=.40$ ). The scales tended to be most informative within $456 \pm 1$ standard deviation of the mean, indicating that the scales most reliably make distinctions 457 around the average level of the attitudes captured by the scales. The scales were least reliable 458 below 1 standard deviation, highlighting that the item content is not calibrated for making fine459 grained distinctions among those who roundly reject the attitudes captured by the scales. Overall 460 the scales had high reliability (mean marginal reliability $=.88$; see Table 2 ). 


\section{The Trumpism factor}

At each assessment wave, the IFAs revealed that all the items across the scales could be

463 characterized by a large, single factor. Scree plots for the IFAs that included all Trumpism-

464 related items in each wave revealed a mean first to second eigenvalue of 16.76 to 2.50 (or 6.70 to

465 1; see online supplement material OSF), indicating the presence of a large, single factor. The

466 most coherent factor solutions with more than one factor tended to include an additional factor

467 defined by items about police and racial attitudes items (occasionally an immigration factor

468 would emerge as well), though all these factors tended to be highly correlated $(r \mathrm{~s}>.50)$. The

469 full results for the full-wave 1, 2, 3, 4, 5, and 6 factor solutions can be found in the online

470 supplement materials (OSF).

Results from the higher-order Trumpism factor models can be found in Table 3 including

472 the standardized factor loadings on the higher-order Trumpism factor, lower- and higher-order

473 factor reliability indices, and correlations over time for the available participants. The full list of

474 loadings for the lower- and higher-order factors can be found in the online supplement (OSF).

475 All lower-order factors loaded strongly on the Trumpism higher order factors $($ mean $\lambda=.87)$.

476 Consequently, the latent factor reliability of the Trumpism factors was high (mean $\omega=.94$ and

477 mean $H=.97)[100]$. The correlation between Trumpism factor scores across different waves

478 ranged from $r=.85$ to $r=.90$, indicating high rank-order stability over the time. Together,

479 results indicate a stable, coherent, and reliable Trumpism factor across waves despite differences

480 in the number and nature of scales at each wave (see Figure 3 for visual depiction). 
Table 3. Lower-Order Factor Loadings on Higher-Order Trumpism Factor, Factor Reliability, and Correlations Over Time.

\begin{tabular}{|c|c|c|c|c|c|c|c|c|c|c|c|c|}
\hline & \multicolumn{3}{|c|}{ Summer 2020} & \multicolumn{4}{|c|}{ Autumn 2020} & \multicolumn{5}{|c|}{ Winter 2021} \\
\hline & $\lambda$ & $\omega$ & $H$ & $\lambda$ & $\omega$ & $H$ & $r_{\mathrm{t}-1}$ & $\lambda$ & $\omega$ & $H$ & $r_{\mathrm{t}-1}$ & $r_{\mathrm{t}-2}$ \\
\hline Trump Approval & .92 & -- & -- & .97 & -- & -- & .90 & .93 & -- & -- & .87 & .83 \\
\hline Police Attitudes & .97 & .94 & .96 & .86 & .95 & .98 & .90 & .76 & .88 & .94 & .88 & .87 \\
\hline Race \& & & & & & & & .88 & & & & .87 & .88 \\
\hline Immigration & .81 & .93 & .94 & .89 & .91 & .92 & & .83 & .92 & .93 & & \\
\hline Attitudes & & & & & & & & & & & & \\
\hline Media Bias & -- & -- & -- & .86 & .94 & .95 & -- & .92 & .94 & .96 & -- & .91 \\
\hline Pro-Gun Attitudes & .67 & -- & -- & .79 & .87 & .88 & .63 & .82 & .88 & .88 & .59 & .90 \\
\hline Rigged Election & -- & -- & -- & -- & -- & -- & -- & .97 & .98 & .99 & -- & -- \\
\hline Pro-Insurrection & -- & -- & -- & -- & -- & -- & -- & .92 & .94 & .97 & -- & -- \\
\hline Trump Idolatry & -- & -- & -- & -- & -- & -- & -- & .97 & .96 & .97 & -- & -- \\
\hline Trumpism & -- & .91 & .96 & -- & .94 & .96 & .90 & -- & .97 & .98 & .85 & .90 \\
\hline
\end{tabular}

$\lambda=$ standardized factor loading; $\omega=$ Coefficient Omega; $H=H$ index of construct replicability; $r_{\mathrm{t}-1}=$ correlations with the pervious wave of data collection; $r_{\mathrm{t}-2}=$ correlations with data collected two waves prior. Assessments waves were separated by 3 to 4 months. Trump Approval and Summer 2020 Gun Attitudes assessed via a single item and so do not

Figure 3. Conceptual diagram of the Trumpism higher-order factor models across the study period.

At every wave of assessment new Trumpism facets were added. Rank-order stability in

Trumpism factor scores was strong (see Table 2).

\section{Trumpism and Demographic Characteristics}

Table 4 provides means, standard deviations, sample sizes, and mean difference effect 
494 the sample mean, and the mean score for Independents was around the sample mean. Relative to

495 Independents, Republicans had much higher Trumpism factor scores (mean $d$ across time $=.97$ ),

496 and Democrats had lower Trumpism factor scores (mean $d$ across time $=-.70$ ), while

497 Republicans also had much higher Trumpism scores than Democrats (mean $d$ across time $=$

498 1.84).

Table 4. Descriptive Statistics and Group Differences in Trumpism.

\begin{tabular}{|c|c|c|c|c|c|c|c|c|c|c|c|c|}
\hline & \multicolumn{4}{|c|}{ Summer 2020} & \multicolumn{4}{|c|}{ Autumn 2020} & \multicolumn{4}{|c|}{ Winter 2021} \\
\hline & $\mathrm{M}$ & SD & $n$ & $d$ & $\mathrm{M}$ & SD & $n$ & $d$ & $\mathrm{M}$ & SD & $n$ & $d$ \\
\hline Sex & & & & & & & & & & & & \\
\hline Women & -.06 & .83 & 531 & & -.06 & .81 & 513 & & -.03 & .83 & 512 & \\
\hline Men & .09 & .98 & 477 & .16 & .09 & .99 & 491 & .16 & .05 & .97 & 493 & .09 \\
\hline Race & & & & & & & & & & & & \\
\hline White & .12 & .09 & 777 & & .12 & .92 & 757 & & .08 & .93 & 771 & \\
\hline Black & -.60 & .72 & 135 & -.89 & -.48 & .68 & 144 & -.75 & -.37 & .73 & 134 & -.54 \\
\hline Other & -.09 & .79 & 85 & -.25 & -.16 & .83 & 88 & -.32 & -.02 & .79 & 85 & -.12 \\
\hline Age & & & & & & & & & & & & \\
\hline $30-59$ & .08 & .86 & 537 & & .09 & .87 & 530 & & .07 & .88 & 534 & \\
\hline Under 30 & -.22 & .84 & 182 & -.36 & -.04 & .83 & 182 & -.15 & .06 & .85 & 187 & -.02 \\
\hline 60 and Older & .01 & .98 & 283 & -.08 & -.11 & 1.00 & 286 & -.20 & -.15 & .95 & 280 & -.24 \\
\hline Annual Income & & & & & & & & & & & & \\
\hline$\$ 50,000-\$ 100,000$ & .03 & .93 & 370 & & -.07 & .99 & 336 & & -.02 & .91 & 354 & \\
\hline Below $\$ 50,000$ & -.01 & .84 & 296 & -.04 & .01 & .82 & 349 & .08 & .07 & .87 & 333 & .11 \\
\hline Above $\$ 100,000$ & .01 & .93 & 342 & -.02 & .10 & .90 & 319 & .18 & -.02 & .91 & 318 & .00 \\
\hline Education & & & & & & & & & & & & \\
\hline 4 Year College Degree or More & -.05 & .89 & 650 & & -.01 & .94 & 569 & & -.06 & .91 & 573 & \\
\hline No 4 Year College Degree & .12 & .91 & 358 & .19 & .04 & .87 & 435 & .06 & .11 & .87 & 432 & .19 \\
\hline Political Party & & & & & & & & & & & & \\
\hline Independent & .05 & .85 & 169 & & .11 & .86 & 184 & & .04 & .82 & 179 & \\
\hline Democrat & -.47 & .74 & 419 & -.65 & -.53 & .74 & 402 & -.78 & -.48 & .75 & 412 & -.66 \\
\hline Republican & .80 & .67 & 261 & .98 & .82 & .61 & 264 & .95 & .78 & .69 & 266 & .98 \\
\hline
\end{tabular}

$\mathrm{M}=$ mean; $\mathrm{SD}=$ standard deviation; $n=$ number of respondents; $d=$ Cohen's $d$. Cohen's $d$ s calculated in relation to referent groups; referent groups are italicized (Women, White, 30-59 Years Old, Annual Income of \$50,000-\$100,000, 4 Year College Degree or More, and Democrat). Note that all three waves of data are included in this table for clarity of presentation, however the Trumpism Factor incorporated a different number of scales of each wave, and the majority of participants only provided responses during one wave of data collection. Accordingly, direct comparisons across waves should be made cautiously as both the Trumpism factor and participants are changing over time.

499

500

Other than political party, the largest demographic differences were observed among

501 White, Black, and other non-White participants. Across time, White participants scored highest 
502 on the Trumpism factor, while Black participants scored much lower (mean $d=-.73$ compared to 503 White participants), and other non-White participants on average scored in between (mean $d=-$ 504.23 compared to White participants). Notably, these differences appear to get smaller over time, 505 however, this is likely an artifact of the number of scales included changing over time.

506 Specifically, the largest difference between White and Black participants was that Black

507 participants had much lower positive attitudes toward police as measured on the Police Attitudes 508 scale ( $d \mathrm{~s}=-.96,-.87$, and -.86 at Summer 2020, Autumn 2020, and Winter 2021, respectively), 509 and so as more scales were added to the Trumpism factor over time the contribution of Police $510 \quad$ Attitudes on factor scores was diluted.

Other demographic trends were less pronounced relative to racial differences. Men scored 512 somewhat higher than women over time (mean $d=.14$ ). Younger (mean $d=-.18$ compared to 513 middle aged participants) and older (mean $d=-.17$ compared to middle aged participants)

514 participants scored lower than middle aged participants over time. From Summer 2020 to Winter 515 2021, the mean differences for younger participants decreased, while those for older participants 516 increased, again likely in part due to the addition of new scales (e.g., younger participants 517 endorse less positive police attitudes on average). There were few consistent trends across 518 income groups, with higher-income participants scoring higher during the Fall of $2020(d=.18$ 519 compared to middle income participants), and lower income participants scoring higher in the 520 Winter of 2021 ( $d=.11$ compared to middle income participants). Except for the Fall of 2020, 521 participants without a Bachelor's-level college degree tended to have slightly higher Trumpism 522 scores than those with a Bachelor's-level college degree (ds of .19). Standardized regression coefficients from the multiple regression interaction models are 524 reported in Table 5. The most consistently observed trend was the main effect of race; these 
525 coefficients were non-trivial in magnitude, and the confidence intervals did not include 0 (mean

$526 \beta=.18$ ). A two-way interaction of non-trivial magnitude between race and age was observed in

527 both the Autumn $2020(\beta=.23 ; 95 \%$ CI: .09, .37) and Winter $2021(\beta=.29 ; 95 \%$ CI: .11, .47)

528 data, while three-way interactions between sex, race, and income were observed in the Summer

$5292020(\beta=.18 ; 95 \%$ CI: .04, .33) and Winter $2021(\beta=.19 ; 95 \%$ CI: .03, .33) data. Although

530 these interactions should be interpreted cautiously and replicated in larger samples, given their

531 magnitude and presence in two out of three waves of data, we briefly discuss them here and have 532 provided graphic illustrations of these interactions in Figures 1 and 2. 
Table 5. Standardized Regression Coefficients from Multiple Regression Models.

\begin{tabular}{|c|c|c|c|}
\hline & Summer 2020 & Autumn 2020 & Winter 2021 \\
\hline $\begin{array}{l}\text { Sex, Race, and Age } \\
\text { Men } \\
\text { White } \\
\text { Age } \\
\text { Men x White } \\
\text { Men x Age } \\
\text { White x Age } \\
\text { Men x White x Age }\end{array}$ & $\begin{array}{c}.12 \\
{[-.02, .26]} \\
. \mathbf{2 6} \\
{[. \mathbf{1 8}, .34]} \\
-.01 \\
{[-.23, .18]} \\
-.09 \\
{[-.24, .06]} \\
-.10 \\
{[-.29, .09]} \\
.18 \\
{[-.01, .37]} \\
.03 \\
{[-.18, .21]} \\
\end{array}$ & $\begin{array}{c}.02 \\
{[-.10, .15]} \\
. \mathbf{1 7} \\
{[. \mathbf{1 0}, .23]} \\
\mathbf{- . 1 9} \\
{[-. \mathbf{3 2},-.06]} \\
.05 \\
{[-.09, .20]} \\
.03 \\
{[-.15, .20]} \\
. \mathbf{2 3} \\
{[. \mathbf{0 9}, .37]} \\
-.10 \\
{[-.29, .08]} \\
\end{array}$ & $\begin{array}{c}.07 \\
{[-.05, .19]} \\
. \mathbf{1 0} \\
{[. \mathbf{0 3}, .18]} \\
\mathbf{- . 3 3} \\
{[-.50,-.15]} \\
-.02 \\
{[-.15, .12]} \\
.01 \\
{[-.15, .18]} \\
. \mathbf{2 9} \\
{[. \mathbf{1 1}, .47]} \\
-.09 \\
{[-.26, .08]} \\
\end{array}$ \\
\hline $\begin{array}{l}\text { Sex, Race, and Income } \\
\text { Men } \\
\text { White } \\
\text { Income } \\
\text { Men x White } \\
\text { Men x Income } \\
\text { White x Income } \\
\text { Men x White x Income }\end{array}$ & $\begin{array}{c}.08 \\
{[-.03, .20]} \\
. \mathbf{2 3} \\
{[. \mathbf{1 6}, .30]} \\
.02 \\
{[-.11, .15]} \\
-.01 \\
{[-.14, .12]} \\
-. .16 \\
{[-.29,-.02]} \\
-.03 \\
{[-.17, .10]} \\
. \mathbf{1 8} \\
{[. \mathbf{0 4}, . \mathbf{3 3}]}\end{array}$ & $\begin{array}{c}.02 \\
{[-.10, .14]} \\
. \mathbf{1 7} \\
{[. \mathbf{1 1}, .24]} \\
-.03 \\
{[-.13, .07]} \\
.07 \\
{[-.07, .21]} \\
.06 \\
{[-.08, .19]} \\
-.03 \\
{[-.15, .09]} \\
.02 \\
{[-.14, .16]}\end{array}$ & $\begin{array}{c}.08 \\
{[-.03, .20]} \\
\mathbf{. 1 4} \\
{[. \mathbf{0 7}, .21]} \\
.06 \\
{[-.07, .20]} \\
-.03 \\
{[-.17, .10]} \\
-.12 \\
{[-.27, .07]} \\
\mathbf{- . 1 8} \\
{[-. \mathbf{3 2},-.03]} \\
\mathbf{. 1 9} \\
{[. \mathbf{0 3}, . \mathbf{3 3}]}\end{array}$ \\
\hline $\begin{array}{l}\text { Sex, Race, and Education } \\
\text { Men } \\
\text { White } \\
\text { Education } \\
\text { Men x White } \\
\text { Men x Education } \\
\text { White x Education } \\
\text { Men x White x Education }\end{array}$ & $\begin{array}{c}.09 \\
{[-.03, .21]} \\
.22 \\
{[. \mathbf{1 5}, .29]} \\
-.06 \\
{[-.21, .10]} \\
.01 \\
{[-.12, .15]} \\
-.03 \\
{[-.20, .14]} \\
-.08 \\
{[-.24, .07]} \\
.05 \\
{[-.13, .21]}\end{array}$ & $\begin{array}{c}.03 \\
{[-.10, .15]} \\
. \mathbf{1 7} \\
{[. \mathbf{1 0}, .23]} \\
\mathbf{- . 1 3} \\
{[-.25,-.01]} \\
.07 \\
{[-.07, .21]} \\
.07 \\
{[-.08, .24]} \\
.03 \\
{[-.10, .16]} \\
-.02 \\
{[-.20, .14]}\end{array}$ & $\begin{array}{c}.09 \\
{[-.02, .20]} \\
\mathbf{. 1 4} \\
{[\mathbf{. 0 7}, .21]} \\
-.09 \\
{[-.24, .07]} \\
-.02 \\
{[-.15, .11]} \\
-.11 \\
{[-.27, .05]} \\
-.06 \\
{[-.22, .10]} \\
.11 \\
{[-.05, .28]}\end{array}$ \\
\hline
\end{tabular}

Standardized regression coefficients presented. Age, income, and education were grand mean centered prior to the computation of the interaction terms. 95\% confidence intervals presented in brackets underestimates; confidence intervals derived via non-parametric percentile bootstrapping with 10,000 random draws. Coefficients with confidence intervals that do not include 0 are presented in bold. Note that all three waves of data are included in this table for clarity of presentation, however the Trumpism Factor incorporated a different number of scales of each 
wave, and the majority of participants only provided responses during one wave of data collection. Accordingly, direct comparisons across waves should be made cautiously as both the Trumpism factor and participants are changing over time.

Figure 4 provides an illustration of the interaction observed between race and age (the

Figure 4. Illustration of the Two-Way Interaction Between Race and Age.

Graphic is based on the unstandardized parameter estimates from the Winter 2021 model.

Trumpism factor scores are on the $\mathrm{Y}$ axis. Younger and Older represent $-/+0.5$ standard deviation from the grand mean centered age variable.

Figure 5. Illustration of the Three-Way Interaction Between Sex, Race, and Income. Figure 4. Illustration of the Three-Way Interaction Between Sex, Race, and Income.

Trumpism factor scores are on the $\mathrm{Y}$ axis. Lower and Higher Income represent $-/+0.5$ standard deviation from the grand mean centered income variable.

544 White participants consistently scored lower on Trumpism than White participants, and income

545 did not appear to be related to these trends. However, among White participants women with

546 higher incomes scored lower on Trumpism, while men with higher income scored higher on

547 Trumpism. That is, among White participants the association between income and Trumpism

548 was in opposite directions across women and men. 


\section{Trumpism and COVID-19}

The odds ratios and correlations between Trumpism and a COVID-19 diagnosis and other outcomes across waves are presented in Table 6. We include the zero-order or unadjusted associations as well as the associations after adjusting for age, sex, race, income, and education (political party was not included given the large degree of overlap with the Trumpism factor scores). Results from logistic regressions showed that a one standard deviation increase in Trumpism scores was associated with a roughly $50 \%$ increase in the odds of a positive COVID19 diagnosis at wave 3 (Winter 2021) but was not associated with a significant increase in the odds of a positive diagnosis at waves 1 (Summer 2020) and 2 (Autumn 2020). After adjusting for demographic variables, the association between Trumpism scores and a COVID-19 diagnosis at wave 3 was only slightly diminished, and the association with our broad definition of a COVID19 diagnosis remained significant, but the association with our narrow definition of COVID-19 was no longer significant at $p<.005(\mathrm{OR}=1.48, p<.01)$.

Correlations between Trumpism scores and the other COVID-19 variables were generally medium to large. Across waves, Trumpism was associated with greater skepticism regarding the severity of COVID-19 ( $r=.69)$, less approval of government restrictions (mean $r=-.50)$, fewer

565 COVID-19 safety behaviors (mean $r=-.33$ ), more anti-vax attitudes (mean $r=.40$ ) and greater COVID-19 vaccine hesitancy (mean $r=.27$ ). Notably, although most associations were similar

567 in magnitude over time, the correlation between Trumpism and willingness to receive a COVID-

56819 vaccine more than doubled in size from Autumn 2020 to Winter 2021 ( $r$ s from -.16 to -.38).

569 Controlling for the demographic covariates did little to change these associations (mean $r \mathrm{~s}= \pm$ $570 \quad .39$ and .38 with and without covariates, respectively). 
Table 6

Trumpism and COVID-19 Variables

\begin{tabular}{|c|c|c|c|c|c|c|c|c|c|}
\hline & \multicolumn{3}{|c|}{ Summer 2020} & \multicolumn{3}{|c|}{ Autumn 2020} & \multicolumn{3}{|c|}{ Winter 2021} \\
\hline & $\%$ & Unadjusted & Adjusted & $\%$ & Unadjusted & Adjusted & $\%$ & Unadjusted & Adjusted \\
\hline \multicolumn{10}{|l|}{ COVID-19 diagnosis } \\
\hline Narrow & 0.5 & 1.12 & 1.50 & 1.9 & 1.06 & 1.12 & 5.6 & 1.53 & 1.48 \\
\hline Broad & 2.8 & 1.08 & 1.20 & 4.3 & 1.34 & 1.37 & 9.1 & 1.50 & 1.44 \\
\hline Approve government restrictions & & -.44 & -.44 & & -.53 & -.51 & & -.53 & -.49 \\
\hline Social distancing & & -.28 & -.26 & & -.29 & -.27 & & -.35 & -.33 \\
\hline Mask wearing & & -.36 & -.32 & & -.34 & -.33 & & -.38 & -.35 \\
\hline COVID-19 skepticism & & -- & -- & & -- & -- & & .69 & .67 \\
\hline Anti-vax attitudes & & -- & -- & & .33 & .37 & & .46 & .48 \\
\hline COVID-19 vaccine hesitancy & & -- & -- & & .16 & .14 & & .38 & .38 \\
\hline
\end{tabular}
.33

Unadjusted = zero-order association between Trumpism and COVID variables; Adjusted = association between Trumpism and COVID-19 variables after controlling for sex, race, age, income, and educational attainment. Associations with COVID-19 diagnosis are odds ratios. Bold $=p<.005$, Italics $=p<.01$. All other associations are correlations, which are all significant at $p<.001$. Note that all three waves of data are included in this table for clarity of presentation, however the Trumpism Factor incorporated a different number of scales of each wave, and the majority of participants only provided responses during one wave of data collection. Accordingly, direct comparisons across waves should be made cautiously as both the Trumpism factor and participants are changing over time. 


\section{Discussion}

Trumpism as a political force within the United States has had a dramatic influence on its

576 politics, culture, and responses to public health and economic crises. We began the process of

577 evaluating psychometric measures of several facets (e.g., approval of Donald Trump, attitudes

578 about race, immigration, policing, news media, etc.) of Trumpism and testing whether the

579 covariance among these measures could be accounted for by a single factor consistent with a

580 coherent political ideology. Our analyses showed that the items designed to assess a specific

581 facet construct (e.g., attitudes about race and immigration) exhibited strong psychometric

582 properties (e.g., high information, high internal consistency, reliability) and that scores on scales

583 designed to measure facets of Trumpism exhibited high correlations among each other that were

584 well accounted for by a single, broad factor. This broad factor was also evident when examining

585 the covariance at the item-level (i.e., items across different scales), which is additional evidence

586 that the content across scales is representative of a consistent and coherent political orientation.

587 The Trumpism factor had high test-retest stability over 3- and 6-month intervals (latent $r=.90$

588 and .85 , respectively) despite changes to its content, indicating this Trumpism factor measures a 589 stable trait construct.

We found that the Trumpism factor was strongly correlated with beliefs about a rigged

5912020 Presidential election and the Insurrection of January 6, 2021. While these are highly

592 politicized events, it is important to note these events could not have been predicted in the

593 summer of 2020, but quickly came to be the latest expression of the continuing evolution of the

594 Trumpism construct. Further, what seems like an extreme position today becomes the median

595 Trumpist position of tomorrow. For example, beliefs of a rigged election are now the majority opinion among Republicans [101-102], and the narrative of Capitol rioters as patriots gained 
597 substantial ground in the following months [103]. These shifts in attitudes likely point to more

598 extreme anti-democratic, authoritarian, and violent actions in the future. For example, several

599 state legislatures have either succeeded in or are attempting to change voting laws that would

600 have the effect of suppressing voters who, based on demographic characteristics, are more likely

601 to vote for Democratic candidates [7,91]. There are also reports of attempts by Trump and

602 current government officials to plan for "legal" ways to overturn the results of future elections

603 [8-9] that would subvert free and fair elections. Consequently, accurate measurement of

604 Trumpism could provide predictive value in anticipating future political events and debates over

605 public policy and help to develop strategies to forestall anti-democratic attempts to gain control

606 of the U. S. government.

607 Correlates of Trumpism

In addition to internal and structural validity, the Trumpism factor also exhibited

609 theoretically consistent associations with demographic variables. For example, Trumpism was

610 especially high among participants affiliated with the Republican party and low among those

611 affiliated with the Democratic party, and higher among White participants relative to non-White

612 participants, especially Black participants. We did not detect main effects of sex and income on

613 Trumpism, though we did detect a three-way interaction among sex, income, and race such that

614 higher income was associated with higher Trumpism among White men, and lower Trumpism

615 among White women. Age was associated with lower Trumpism, but this main effect was

616 moderated by race such that Trumpism was especially low among older non-White participants.

617 The relatively weak associations with sex, education, and income may seem surprising

618 given media narratives that Trumpism is more popular among men, older age, lower income, and

619 lower education groups. However, income and education are stratified by race with mean-levels 
620 being lower among Black Americans relative to White Americans [104-105]. Further, polling

621 results indicate Trump voters have higher incomes than non-Trump voters, contradicting this

622 narrative [106-107]. Consequently, when media reports describe Trumpism as having great

623 appeal among lower educated, lower income, or working-class Americans, a more accurate

624 description would be that Trumpism is popular among lower educated and lower income White

625 Americans (i.e., the "White working class").

It may be helpful to translate how findings and analyses from psychologically oriented

627 individual differences research relate to media reports. One is that the main effect of race is

628 much stronger than the main effects and interactions with sex, income, and education. From the

629 perspective of scientific parsimony and reliable effects, what these results tell us about

630 understanding American politics is that race is the dominant demographic variable of

631 importance. Large and reliable effects are difficult to change, however, and so don't have a large

632 impact on the dynamic process of winning elections, because they are "baked in". Consequently,

633 elections are situations when interactions (defined as the intersection of demographic variables),

634 though small, often have high practical consequences. Specifically, political scientists have

635 detected a significant sorting in American politics over the past 50 years such that intersecting

636 social identities have become more strongly aligned with political party affiliation [108-109]. In

637 terms of winning elections, then, it is important for political parties to identify subgroups to

638 target appeals that will improve their voting margins, and so it is these interaction effects on

639 which elections are fought and won.

640 Trumpism and COVID-19

While Trumpism is sometimes characterized as similar to being a fan of a sports team,

642 our findings on the links between Trumpism and the COVID-19 variables indicate the 
643 consequences of organizing your behavior around "owning the libs" can be dire, even fatal.

644 Trumpism scores were associated with a roughly $50 \%$ increase in the odds of a COVID-19

645 diagnosis by the early months of 2021 and were strongly associated with an overall skepticism

646 about the health risks of COVID-19, disapproval of government actions to mitigate the spread of

647 the virus, and failure to engage in personal behaviors to reduce the spread of infection including

648 wearing masks and following social distancing recommendations. Trumpism was also associated

649 with anti-vax beliefs and hesitancy to receive a COVID-19 vaccine, associations that increased

650 from autumn 2020 (prior to vaccine availability) to early 2021 (initial vaccine availability)

651 suggesting an increasing politicization of vaccination over time (the association between

652 Trumpism and a positive COVID-19 followed a similar trend, though this could be due to greater

653 statistical power as the prevalence of infection increased). Failure to vaccinate against COVID-

65419 is especially consequential for personal and public health as it is by far the most effective

655 measure to prevent death and serious illness while also reducing the risk of infection and spread

656 [69]. Engaging in persistent inaccurate, irrational, and illogical rhetoric regarding vaccination by

657 a vocal minority contributes to an environment of misinformation and hardens anti-vax and

658 vaccine hesitant beliefs, even among people who do not hold Trumpism attitudes. Consequently,

659 the lack of vaccination among a significant minority of Americans who disproportionately hold

660 Trumpism political beliefs has contributed to thousands of preventable deaths, stressed the

661 medical care system, and contributed to prolonging the pandemic, including its negative

662 economic, social, and psychological consequences.

\section{Limitations and Future Directions}

664 The study has important limitations. One, the sample size lacked adequate power to 665 reliably detect certain higher-order interactions (i.e., three or more variables), and the ones that 
666

667

668

669

670

671

672

673

674

675

676

677

678

679

680

681

682

683

684

685

686

687

688

exceeded statistical significance should be interpreted cautiously. Therefore, future analyses focused on potential interaction effects should do so with larger samples. Two, we did not present analyses of additional correlates of Trumpism such as personality, mental health, and political engagement to further characterize the psychological structure of Trumpism. We plan to do so in future analyses. Three, while we adjusted for demographic variables when estimating the associations between Trumpism and COVID-19 variables, there may be other variables that can account for some or all these associations. Consequently, we plan to examine the incremental predictive power of Trumpism relative to other predictors of COVID-19 variables in future analyses. Four, while the sample was representative of the U.S. population in terms of age, sex, and race, it included a greater proportion of persons with higher educational attainment (i.e., undergraduate or graduate degree) and persons aligned with the Democratic party relative to people that are political independents, unaffiliated, or non-voters. While this can bias the estimates of mean differences, the correlation structure among measures is unlikely to be strongly affected (assuming adequate but lower representation of these groups in the sample), which was the focus of our analyses.

For future research, it will be important to continue to describe the Trumpism construct including its boundaries and additional facets. For example, we have not yet examined associations between the current Trumpism content and topics such as attitudes about abortion, Christian nationalism, White nationalism, economic and policy issues such as trade policy, taxes, social welfare programs, and foreign policy, as well as conspiratorial beliefs such as QAnon. Further, Trumpism is a dynamic construct and continues to evolve with current political issues. For example, since the last wave of data was collected in this report, the topic of critical race theory and the teaching of race-related historical content in public schools has become a political 
689 issue that is strongly tied to politicians with Trumpist ideology [110-111]. In some states, this

690 has led to the proposal or passage of state laws that restrict the framing, description, and

691 potentially the content of historical information presented in classrooms with penalties for

692 teachers who violate these laws. These laws are especially problematic in that the teaching of

693 accurate historical information (e.g., past laws that restricted the activities and rights of people

694 based on race) might be interpreted as criminal acts. The Trumpism measures in this report may

695 serve as anchor constructs to help to track and integrate changes in American political attitudes.

696 It will also be important to use Trumpism measures to attempt to predict the course of

697 political and health attitudes and behaviors. Despite the change in presidential administrations,

698 the COVID-19 pandemic continues to have a major societal impact and source of conflict that is

699 strongly politicized. Trumpist attitudes may be informative in predicting reactions to government

700 and business policies related to the COVID-19 pandemic, especially resistance that could be

701 disruptive to important activities (e.g., mitigation measures at public schools). More ominously,

702 there has been an increase in the acceptability of using anti-democratic tactics and even violence

703 to hold or seize political power [112-113]. Linking Trumpism to these anti-democratic attitudes

704 may help to identify extremist groups and individuals that could threaten democratic institutions.

705 Finally, the factors that contribute to embracing a Trumpist ideology are important to understand.

706 While contemporary events are clearly important, it is possible that more distal person-level

707 characteristics and experiences can serve as predictors of susceptibility to a similar political

708 orientation. Adding Trumpism measures to longitudinal cohorts would make it possible to link

709 current political ideology and its behavioral sequelae (e.g., COVID-19 safety behaviors) to prior

710 characteristics (e.g., personality, mental health, attitudes), some that may be present as early as 
711 childhood. Such research may help to understand the psychological structure of persons that

712 select into similar political and cultural tribes.

713

714 References

715 [1] Haltiwanger J. Republicans have built a cult of personality around Trump that glosses over

716 his disgraced presidency [Internet]. Business Insider. Business Insider; 2021. Available

717 from: https://www.businessinsider.com/republicans-have-built-a-cult-of-personalty-

$718 \quad$ around-trump-2021-3

719 [2] Krauss L. Trump's Anti-Science Campaign [Internet]. The New Yorker; 2016. Available from: https://www.newyorker.com/news/news-desk/trumps-anti-science-campaign

[3] Motta M. The dynamics and political implications of anti-intellectualism in the United States. American Politics Research. 2018 May;46(3):465-98.

[4] Reyes A. I, Trump: The cult of personality, anti-intellectualism and the Post-Truth era. Journal of language and politics. 2020 Oct 19;19(6):869-92.

[5] Scherer M. White identity politics drives Trump, and the Republican Party under him [Internet]. The Washington Post, 2019. Available from: https://www.washingtonpost.com/politics/white-identity-politics-drives-trump-and-therepublican-party-under-him/2019/07/16/a5ff5710-a733-11e9-a3a6ab670962db05_story.html roundup: July 2021 [Internet]. Brennan Center for Justice, 2021. Available from: 
https://www.brennancenter.org/our-work/research-reports/voting-laws-roundup-july$\underline{2021}$

[7] Gardner A, Rabinowitz K, Stevens H. How GOP-backed voting measures could create hurdles for tens of millions of voters [Internet]. The Washington Post, 2021. Available from: https://www.washingtonpost.com/politics/interactive/2021/voting-restrictions$\underline{\text { republicans-states/ }}$

[8] Riccardi N. Trump's grip on GOP sparks fears about democratic process [Internet]. AP News, 2021. Available from: https://apnews.com/article/michael-pence-donald-trump-capitolsiege-campaign-2016-election-2020-5af20be3c4533a8a34763e82341eaca1

[9] Riccardi N, Izaguirre A. Conservative group boasts of secret role in voting laws [Internet]. AP News, 2021. Available from: https://apnews.com/article/politics-donald-trump-lawsvoting-government-and-politics-c07c55f7dd3ad5847d31d7a5123bb82c

[10] Haberman M. Trump proud to be a birther [Internet]. POLITICO, 2021. Available from: https://www.politico.com/story/2011/03/trump-proud-to-be-a-birther-052252

[11] Hughey MW. Show me your papers! Obama's birth and the whiteness of belonging. Qualitative Sociology. 2012 Jun;35(2):163-81.

[12] Tope D, Pickett JT, Cobb RJ, Dirlam J. Othering Obama: Racial attitudes and dubious beliefs about the nation's first black president. Sociological Perspectives. 2014 Dec;57(4):450-69.

[13] Haney-López I. Dog whistle politics: How coded racial appeals have reinvented racism and wrecked the middle class. Oxford University Press; 2015 Feb 19. 
[14] Transcript: Donald Trump's full immigration Speech, annotated [Internet]. Los Angeles Times, 2016. Available from: https://www.latimes.com/politics/la-na-pol-donald-trumpimmigration-speech-transcript-20160831-snap-htmlstory.html

[15] Vidal XM. Immigration politics in the 2016 election. PS: Political Science \& Politics. 2018 Apr;51(2):304-8.

[16] Hawley G. Ambivalent nativism: Trump supporters' attitudes toward Islam and Muslim immigration. Brookings Institution. 2019.

[17] ICE Union Endorses Trump [Internet]. Politico, 2016. Available from: https://www.politico.com/story/2016/09/immigration-customs-enforcement-unionendorses-trump-228664

[18] Gramlich J. How border apprehensions, ICE arrests and deportations have changed under Trump. Pew Research Center. 2020 Mar;2.

[19] Naylor B. Read Trump's Jan. 6 speech, a key part of impeachment trial [Internet]. NPR, 2021. Available from: https://www.npr.org/2021/02/10/966396848/read-trumps-jan-6speech-a-key-part-of-impeachment-trial

[20] Lange J. Trump wins backing of largest U.S. police union as he touts 'law and order' [Internet]. Reuters, 2020. Available from: https://www.reuters.com/article/us-usaelection-law-enforcement/trump-wins-backing-of-largest-u-s-police-union-as-he-touts$\underline{\text { law-and-order-idUSKBN25V22V }}$

[21] Serwer A. Trump is Winning His War on the FBI [Internet]. The Atlantic, 2019. Available from: https://www.theatlantic.com/ideas/archive/2019/09/fbi-trump-comey/597523/

[22] McArdle T. The 'law and order' campaign that won Richard Nixon the White House 50 years ago [Internet]. The Washington Post, 2018. Available 
from: https://www.washingtonpost.com/history/2018/11/05/law-order-campaign-thatwon-richard-nixon-white-house-years-ago/

[23] Richard Nixon Foundation. President-elect Richard Nixon declares victory in 1968 [Video]. YouTube, 2012. Available from: https://www.youtube.com/watch?v=v3xT-1SIC7A

[24] Cherone H. Cops warned after car with 'Make America Great Again' hat seen near protest [Internet]. DNAinfo, 2017. Available from: https://www.dnainfo.com/chicago/20170123/downtown/cops-warned-after-car-withmake-america-great-again-hat-seen-near-protest/

[25] Hawkins D. San Antonio cops face discipline for wearing 'Make America Great Again' hats in Trump video [Internet]. The Washington Post, 2019. Available from: https://www.washingtonpost.com/news/morning-mix/wp/2016/10/12/san-antonio-copsface-discipline-for-wearing-make-america-great-again-hats-in-trump-video/

[26] Swain RD. Negative black stereotypes, support for excessive use of force by police, and voter preference for Donald Trump during the 2016 presidential primary election cycle. Journal of African American Studies. 2018 Mar;22(1):109-24.

[27] Chaney C, Robertson RV. Racism and police brutality in America. Journal of African American Studies. 2013 Dec;17(4):480-505.

[28] Tolliver WF, Hadden BR, Snowden F, Brown-Manning R. Police killings of unarmed Black people: Centering race and racism in human behavior and the social environment content. Journal of Human Behavior in the Social Environment. 2016 May 18;26(3-4):279-86.

[29] Weitzer R, Tuch SA. Racially biased policing: Determinants of citizen perceptions. Social forces. 2005 Mar 1;83(3):1009-30. 
[30] Beckett L, Siddiqui S. Trump and Clinton on guns: two visions of race, justice and policing in the US [Internet]. The Guardian, 2016. Available from: https://www.theguardian.com/us-news/2016/may/21/trump-clinton-gun-control-policiesrace-policing

[31] Bump P. Donald Trump took 5 different positions on abortion in 3 days [Internet]. The Washington Post, 2016. Available from: https://www.washingtonpost.com/news/thefix/wp/2016/04/03/donald-trumps-ever-shifting-positions-on-abortion/

[32] Kurtzleben D. The Complicated Importance Of Abortion To Trump Voters [Internet]. NPR, 2020. Available from: https://www.npr.org/2020/09/17/913589176/the-complicatedimportance-of-abortion-to-trump-voters

[33] Martin M. Barborshop: Trump's Contentious, Yet Symbiotic Relationship With The Media [Internet]. NPR, 2017. Available from: https://www.npr.org/2017/04/30/526298029/barbershop-trumps-contentious-yetsymbiotic-relationship-with-the-media

[34] Rutenberg J. The Mutual Dependence of Donald Trump and the News Media [Internet]. The New York Times, 2016. Available from: https://www.nytimes.com/2016/03/21/business/media/the-mutual-dependence-oftrump-and-the-news-media.html

[35] Woodward A. 'Fake news': A guide to Trump's favourite phrase- and the dangers it obscures [Internet]. Independent, 2020. Available from: https://www.independent.co.uk/news/world/americas/us-election/trump-fake$\underline{\text { news-counter-history-b732873.html }}$ 
820 [36] Hemmer N. The Conservative War on Liberal Media Has a Long History [Internet]. The Atlantic, 2014. Available from: https://www.theatlantic.com/politics/archive/2014/01/the-conservative-war-on-liberal$\underline{\text { media-has-a-long-history/283149/ }}$

[37] Beckwith RT. Read a Transcript of President Trump's CPAC Speech [Internet]. Time, 2017. Available from: https://time.com/4682023/cpac-donald-trump-speech-transcript/

[38] Buncombe A. Donald Trump doubles down on 'enemies of the people' attack on media [Internet]. Independent, 2017. Available from: https://www.independent.co.uk/news/world/americas/us-politics/donald-trump-fake$\underline{\text { news-enemies-of-the-people-media-attack-cpac-speech-latest-a7598156.html }}$

[39] Lucey C, Leary A. Donald Trump Presides Over GOP Remade in His Image [Internet]. The Wall Street Journal, 2020. Available from: https://www.wsj.com/articles/donald-trumppresides-over-gop-remade-in-his-image-11598473437

[40] Miller Z, Peoples S. Trump campaign takes steps to prevent a challenge within GOP [Internet]. AP News, 2019. Available from: https://apnews.com/article/north-americadonald-trump-ap-top-news-elections-politics-33438efb7d794b5caf0b60f815192500

[41] Tenpas KD. Tracking turnover in the Trump administration [Internet]. Brookings, 2021. Available from: https://www.brookings.edu/research/tracking-turnover-in-the-trump$\underline{\text { administration/ }}$

[42] Bruine de Bruin W, Saw HW, Goldman DP. Political polarization in US residents' COVID19 risk perceptions, policy preferences, and protective behaviors. Journal of risk and uncertainty. 2020 Oct;61(2):177-94. 
842 [43] Farley R. Trump's partisan spin on reopening states [Internet]. FactCheck.org, 2020. Available from: https://www.factcheck.org/2020/11/trumps-partisan-spin-on-reopening$\underline{\text { states/ }}$

[44] Sanford C. Donald Trump rally speech transcript reading, pa October 31 [Internet]. Rev, 2020. Available from: https://www.rev.com/blog/transcripts/donald-trump-rally-speechtranscript-reading-pa-october-31

[45] Smith S. Unmasked: How Trump's mixed messaging on face-coverings hurt U.S. coronavirus response [Internet]. NBC News, 2020. Available from: https://www.nbcnews.com/politics/donald-trump/calendar-confusion-february-augusttrump-s-mixed-messages-masks-n1236088.

[46] Forgey Q. 'We're not a shipping clerk': Trump tells governors to step up efforts to get medical supplies [Internet]. Politico, 2020. Available from: https://www.politico.com/news/2020/03/19/trump-governors-coronavirus$\underline{\text { medical-supplies-137658 }}$

[47] Ronayne K, Lemire J. Flatter or fight? Governors seeking help must navigate Trump [Internet]. AP News, 2020. Available from: https://apnews.com/article/donald-trumpap-top-news-virus-outbreak-mi-state-wire-public-health$\underline{\text { f9fb8c41b7f8acc215e3ec78ca32210a }}$

[48] Zamarripa R, Weller CE. Only a National Strategy To Combat COVID-19 Can Ensure a FULL Economic Recovery [Internet]. Center for American Progress, 2020. Available from: https://www.americanprogress.org/article/national-strategy-combat-covid-19-canensure-full-economic-recovery/ 
[49] Jaiswal J, LoSchiavo C, Perlman DC. Disinformation, misinformation and inequalitydriven mistrust in the time of COVID-19: lessons unlearned from AIDS denialism. AIDS and Behavior. 2020 Oct;24(10):2776-80.

[50] Sherwin BD. Anatomy of a Conspiracy Theory: Law, Politics, and Science Denialism in the Era of COVID-19. Tex. A\&M L. Rev.. 2020;8:537.

[51] Buchanan L, Bui Q, Patel JK. Black lives matter may be the largest movement in U.S. history [Internet]. The New York Times, 2020. Available from: https://www.nytimes.com/interactive/2020/07/03/us/george-floyd-protests-crowd$\underline{\text { size.html }}$

[52] Wamsley L. Derek Chauvin found guilty of George Floyd's murder [Internet]. NPR, 2021. Available from: https://www.npr.org/sections/trial-over-killing-of-georgefloyd/2021/04/20/987777911/court-says-jury-has-reached-verdict-in-derek-chauvins$\underline{\text { murder-trial }}$

[53] Horowitz J. Support for Black Lives Matter declined after George Floyd protests but has remained unchanged since [Internet]. Pew Research, 2021. Available from: https://www.pewresearch.org/fact-tank/2021/09/27/support-for-black-lives-matterdeclined-after-george-floyd-protests-but-has-remained-unchanged-since/ [54] Eaglin JM. To" Defund" the Police. Stan. L. Rev. Online. 2020;73:120.

[55] Levin S. Movement to defund police gains 'unprecedented' support across US [Internet]. The Guardian, 2020. Available from: https://www.theguardian.com/usnews/2020/jun/04/defund-the-police-us-george-floyd-budgets 
885 [56] Gambino L. Trump and Republicans use calls to 'defund the police' to attack Democrats

886

887

888

889

890

891

892

893

894

895

896

897

898

899

900

901

902

903

904

905

906
[Internet]. The Guardian, 2020. Available from: https://www.theguardian.com/usnews/2020/jun/08/trump-republicans-defund-the-police-george-floyd

[57] Ray R, Gilbert KL. Has Trump failed Black Americans? [Internet]. Brookings, 2021. Available from: https://www.brookings.edu/blog/how-we-rise/2020/10/15/has-trumpfailed-black-americans/

[58] Jhaveri I. The rise of the Thin Blue Line at Trump rallies [Internet]. Medium, 2020. Available from: https://towcenter.medium.com/the-rise-of-the-thin-blue-line-attrump-rallies-8f10aed379e1

[59] Dave DM, Friedson AI, Matsuzawa K, Sabia JJ, Safford S. Black lives matter protests and risk avoidance: The case of civil unrest during a pandemic. National Bureau of Economic Research; 2020 Jun 22.

[60] Neyman G, Dalsey W. Black Lives Matter protests and COVID-19 cases: relationship in two databases. Journal of Public Health. 2021 Jun;43(2):225-7.

[61] James N, Menzies M. COVID-19 in the United States: Trajectories and second surge behavior. Chaos: An Interdisciplinary Journal of Nonlinear Science. 2020 Sep 22;30(9):091102.

[62] Kluger J, Wilson C. The US is done with COVID-19, but it isn't done with the US [Internet]. Time, 2020. Available from: https://time.com/5852913/covid-second-wave/

[63] Drake J. The real cause of America's third wave of COVID-19 [Internet]. Forbes, 2020. Available from: https://www.forbes.com/sites/johndrake/2020/12/07/the-real-cause-ofamericas-third-wave-of-covid-19/?sh=2cfbfe6112fd 
[64] Wilson C, Kluger J. Alarming covid-19 data shows Third Wave Brewing for U.S [Internet]. Time, 2020. Available from: https://time.com/5893916/covid-19-coronavirus-third$\underline{\text { wave/ }}$

[65] Van Beusekom M. US leads 19 nations in COVID-19, all-cause death rates [Internet]. CIDRAP, 2020. Available from: https://www.cidrap.umn.edu/newsperspective/2020/10/us-leads-19-nations-covid-19-all-cause-death-rates

[66] Chappell B. 'Enormous and tragic': U.S. has lost more than 200,000 people to COVID-19 [Internet]. NPR, 2020. Available from: https://www.npr.org/sections/coronavirus-liveupdates/2020/09/22/911934489/enormous-and-tragic-u-s-has-lost-more-than-200-000people-to-covid-19

[67] Francisco CA. Understanding the US failure on coronavirus - an essay by Drew Altman. bmj. 2020;370:m3417.

[68] Haffajee RL, Mello MM. Thinking globally, acting locally-The US response to COVID19. New England journal of medicine. 2020 May 28;382(22):e75.

[69] Centers for Disease Control and Prevention. CDC Covid Data tracker [Internet]. Centers for Disease Control and Prevention. Available from: https://covid.cdc.gov/covid-datatracker/\#datatracker-home ; https://covid.cdc.gov/covid-data-tracker/\#rates-by-vaccine-status; https://covid.cdc.gov/covid-data-tracker/\#covidnet-hospitalizations-vaccination

[70] Presidential election process [Internet]. USAGov, 2021. Available from: https://www.usa.gov/election

[71] Resolution regarding the Republican Party Platform [Internet]. The American Presidency Project. UC Santa Barbara, 2020. Available from: 
https://www.presidency.ucsb.edu/documents/resolution-regarding-the-republican-partyplatform

[72] Appelbaum Y. Trump's claim: 'I alone can fix it' [Internet]. The Atlantic, 2016. Available from: https://www.theatlantic.com/politics/archive/2016/07/trump-rnc-speech-alone-fixit/492557/.

[73] Keith T. Amid crises, Trump to give sequel to 'I alone can fix it' convention pledge [Internet]. NPR, 2020. Available from: https://www.npr.org/2020/08/27/906670315/amid-crises-trump-to-give-sequel-toi-alone-can-fix-it-convention-pledge

[74] Sherman M. Electoral College makes it official: Biden won, Trump lost [Internet]. AP News, 2020. Available from: https://apnews.com/article/joe-biden-270-electoralcollege-vote-d429ef97af2bf574d16463384dc7cc1e

[75] Chalfant M. Trump: 'The only way we're going to lose this election is if the election is rigged' [Internet]. The Hill, 2020. Available from: https://thehill.com/homenews/administration/512424-trump-the-only-way-we-are-goingto-lose-this-election-is-if-the

[76] Parks M. Officials Fear A New Normal As Republicans Make Baseless California Fraud Claims [Internet]. NPR, 2021. Available from: https://www.npr.org/2021/09/13/1036696853/if-republicans-lose-the-california-recallelection-they-might-claim-fraud

[77] Eggers AC, Garro H, Grimmer J. No Evidence for Voter Fraud: A Guide To Statistical Claims About the 2020 Election. Working Paper; 2021 Feb 3. 
952 [78] Mascaro L, Tucker E, Jalonick MC, Taylor A. Pro-Trump mob storms US capitol in bid to

953

954

955

956

957

958

959

960

961

962

963

964

965

966

967

968

969

970

971

972

973

974

overturn election [Internet]. AP News, 2021. Available

from: https://apnews.com/article/congress-confirm-joe-biden$\underline{78104 \mathrm{aea} 082995 \mathrm{bbd} 7412 \mathrm{a} 6 \mathrm{e} 6 \mathrm{~cd} 13818}$

[79 Pennycook G, Rand DG. Examining false beliefs about voter fraud in the wake of the 2020 Presidential Election. The Harvard Kennedy School Misinformation Review. 2021.

[80] Berlinski N, Doyle M, Guess AM, Levy G, Lyons B, Montgomery JM, Nyhan B, Reifler J. The effects of unsubstantiated claims of voter fraud on confidence in elections. Journal of Experimental Political Science. 2021:1-6.

[81] Blake A. Trump's 'Big LIE' was bigger than just a stolen election [Internet]. The Washington Post, 2021. Available

from: https://www.washingtonpost.com/politics/2021/02/12/trumps-big-lie-was-bigger$\underline{\text { than-just-stolen-election/ }}$

[82] Counting Electoral Votes in Congress, 3 U.S.C $§ 15$ (1948). Available from: https://uscode.house.gov/statviewer.htm?volume=62\&page $=675$

[83] Rally on Electoral College Vote Certification [Video]. C-SPAN, 2021. Available from: https://www.c-span.org/video/?507744-1/rally-electoral-college-vote-certification

[84] Fandos N, Cochrane E. After Pro-Trump mob storms Capitol, Congress confirms Biden's win [Internet]. The New York Times, 2021. Available from: https://www.nytimes.com/2021/01/06/us/politics/congress-gop-subvert-election.html

[85] President Trump on Election and Breach of the U.S. Capitol [Video]. C-SPAN, 2021. Available from: https://www.c-span.org/video/?507829-1/president-trump-electionbreach-us-capitol 
975 [86] Impeaching Donald John Trump, President of the United States, for high crimes and

976

977

978

979

980

981

982

983

984

985

986

987

988

989

990

991

992

993

994

995

996

997

misdemeanors, H.R.24, 117th Congress, 2021. Available from:

https://www.congress.gov/bill/117th-congress/house-resolution/24

[87] United States Constitution art. I, § 3, cl. 6

[88] Conway K. New Marquette Law School Poll finds majority of Republicans across the nation favor a Trump run for president in 2024, while majority of voters overall are opposed [Internet]. Marquette University, 2021. Available from: https://www.marquette.edu/news-center/2021/new-marquette-law-poll-findsmajority-of-republicans-favor-a-trump-run-for-president-in-2024.php

[89] Conservative political action conference straw poll results [Internet]. C-SPAN, 2021. Available from: https://www.c-span.org/video/?513297-120\%2Fconservative-political$\underline{\text { action-conference-straw-poll-results }}$

[90] Greenwood M. Poll: Trump leads 2024 Republican field with desantis in Distant Second [Internet]. The Hill, 2022. Available from: https://thehill.com/homenews/campaign/591115-poll-trump-leads-2024$\underline{\text { republican-field-with-desantis-in-distant-second?rl=1 }}$

[91] Inskeep S. Why Republicans are moving to fix elections that weren't broken [Internet]. NPR, 2021. Available from: https://www.npr.org/2021/02/28/970877930/why$\underline{\text { republicans-are-moving-to-fix-elections-that-werent-broken }}$

[92] Igielnik R, Keeter S, Hartig H. Behind Biden’s 2020 Victory. Pew Research Center. 2021 Jun 30.

[93] Roberts HA, Clark DA, Hicks BM. To vax or not to vax: Predictors of anti-vax attitudes and COVID-19 vaccine hesitancy prior to widespread vaccine availability. 
998 [94] Samejima F. Estimation of latent ability using a response pattern of graded scores. Psychometrika monograph supplement. 1969 Dec.

1000 [95] Wirth RJ, Edwards MC. Item factor analysis: current approaches and future directions.

$1001 \quad$ Psychological methods. 2007 Mar;12(1):58.

1002 [96] Clark DA, Hicks BM, Angstadt M, Rutherford S, Taxali A, Hyde L, Weigard AS, Heitzeg

1003 MM, Sripada C. The general factor of psychopathology in the Adolescent Brain

1004

1005

1006

1007

[97] Houts CR, Cai L. flexMIRTR: Flexible Multilevel Multidimensional Item Analysis and Test

1008 Scoring User's Manual Version 2.0.

[98] Muthén LK, Muthén BO. Mplus user's guide (Version 8). Los Angeles, CA: Author. 1998.

1009

1010

1011

1012

1013

1014

1015

1016

1017

1018

1019

1020
[99] Falk CF. Are robust standard errors the best approach for interval estimation with nonnormal data in structural equation modeling?. Structural Equation Modeling: A Multidisciplinary Journal. 2018 Mar 4;25(2):244-66.

[100] Rodriguez A, Reise SP, Haviland MG. Evaluating bifactor models: Calculating and interpreting statistical indices. Psychological methods. 2016 Jun;21(2):137.

[101] Kahn C. Half of Republicans say Biden won because of a "rigged" election: Reuters/Ipsos poll [Internet]. Reuters, 2020. Available from: https://www. reuters. com/article/us-usaelection-poll/half-ofrepublicans-say-biden-won-because-of-a-rigged-election-reutersipsos-pollidUSKBN27Y1AJ

[102] Oliphant J, Kahn C. Half of Republicans believe false accounts of deadly U.S. capitol riotReuters/Ipsos poll [Internet]. Reuters, 2021. Available from: https://www.reuters.com/article/us-usa-politics-disinformation- 

idUSKBN2BS0RZ?taid=606af4c8a0a3570001acce1f\&utm_campaign=trueAnthem\%3A \%2BTrending\%2BContent\&utm_medium=trueAnthem\&utm_source=twitter

[103] Mascaro L. Capitol Rally seeks to rewrite Jan. 6 by exalting rioters [Internet]. AP News, 2021. Available from: https://apnews.com/article/joe-biden-donald-trump-capitol-siege$\underline{\mathrm{d} 2 \mathrm{fb} 23 \mathrm{af} 3 \mathrm{f} 01387412 \mathrm{a} 1 \mathrm{a} 00 \mathrm{~b} 4 \mathrm{eac} 531 \mathrm{c}}$

[104] Hanson M. Educational attainment statistics [2022]: Levels by demographic [Internet]. Education Data Initiative, 2021. Available from: https://educationdata.org/educationattainment-statistics

[105] Semega J, Kollar M, Emily S, Creamer J. Income and poverty in the United States: 2019 [Internet]. United States Census Bureau, 2020. Available from: https://www.census.gov/data/tables/2020/demo/income-poverty/p60-270.html [106] Hudak J. A reality check on 2016's economically marginalized. Brookings Institution, November. 2016 Nov 16;16.

[107] National Exit Polls: How Different Groups Voted [Internet] The New York Times, 2020. Available from: https://www.nytimes.com/interactive/2020/11/03/us/elections/exit-pollspresident.html

[108] Greene S. Social identity theory and party identification. Social science quarterly. 2004 Mar;85(1):136-53.

[109] Weir K. Politics is personal. American Psychological Association. 2019;50(10):44.

[110] Anderson B. Explainer: So much buzz, but what is critical race theory? [Internet] AP News, 2020. Available from: https://apnews.com/article/donald-trump-race-andethnicity-racial-injustice-raleigh-fdd428b6f468be56129e5dc780c605cd 
1043 [111] Waxman OB. Critical race theory: The fight over what history kids learn [Internet]. Time, 1044 2021. Available from: https://time.com/6075193/critical-race-theory-debate/

1045 [112] Bartels LM. Ethnic antagonism erodes Republicans’ commitment to democracy.

1046 Proceedings of the National Academy of Sciences. 2020 Sep 15;117(37):22752-9.

1047 [113] Goldmacher S, Haberman M. A year after Capitol Riot, Trump's hold on G.O.P. is

1048 unrivaled [Internet]. The New York Times, 2022. Available

1049 from: https://www.nytimes.com/2022/01/05/us/politics/trump-gop-jan-6.html 